\title{
Improving Nitrogen Fertilizers Efficiency in Soil by Using Nitrification Inhibitor (DMPP)
}

\author{
A.H.A. Hussein 1
}

\begin{abstract}
In the present study, the nitrification inhibitor, DMPP (3,4-dimethyl pyrazole phosphate) was used for inhibiting the nitrogen transformation and reduced the nitrate leaching in two types of soil, i.e. sandy loam and sandy clay loam. Soil columns $(5 \mathrm{~cm}$ diameter and $24 \mathrm{~cm}$ length) were packed with soil at bulk density of $1.5 \mathrm{~g} / \mathrm{cm}^{3}$. Nitrogen fertilizers (urea and ammonium sulphate) were applied at rate of $150 \mathrm{mg} \mathrm{N} /$ column. The soil columns were leached with $150 \mathrm{ml}$ water/5 days and the leachate was collected. The experiment was lasted 40 days. At the end of experimental period the soil was pushed out the columns and sectioned at $5 \mathrm{~cm}$ pieces, then extracted for $\mathrm{N}-\mathrm{NO}_{3}{ }^{-}$ and $\mathrm{N}-\mathrm{NH}_{4}{ }^{+}$.The results showed that DMPP with urea or ammonium sulphate significantly reduced $\mathrm{NO}_{3}^{-}-\mathrm{N}$ leaching. The cumulative leaching losses of soil nitrate under treatment of urea or ammonium sulphate with $1.0 \%$ DMPP, from columns of sandy loam soil were 34.7 and 40.6\% and from column of sandy clay loam soil, were 51.7 and $43.4 \%$ lower than those of soil columns tested with urea or ammonium sulphate application only within the $\mathbf{4 0}$ days observation, respectively. The results also showed that nitrification rate (NR), was reduced as a result of DMPP application. The nitrification rate was reduced from $\mathbf{5 3 . 9 6}$ (with urea only) to $\mathbf{3 6 . 4 6 \%}$ (with urea treated with DMPP) and from 65.92 (with ammonium sulphate only) to $27.92 \%$ (with ammonium sulphate treated with DMPP) in case of sandy loam soil. The corresponding values in case of sandy clay loam soil were from 60.70 to $43.76 \%$ and from 67.46 to $36.59 \%$, respectively. Also, the inhibition percentage of nitrate was 32.43 and $57.64 \%$ with urea and ammonium sulphate treated with DMPP, respectively in case of sandy loam soil. The corresponding values were 27.91 and $45.77 \%$, respectively in case of sandy clay loam soil. It is proposed that DMPP could be used as an effective nitrification inhibitor to control nitrification process, decline $\mathrm{N}$ leaching, and increase the utilization efficiency of applied nitrogen fertilizers besides saving the fertilizers and labor costs.
\end{abstract}

Keywords: 3,4-Dimethyl pyrazole phosphate (DMPP), Nitrification inhibitors, Nitrate leaching, Nitrogen fertilizer, sandy loam soil, sandy clay loam soil.

\section{INTRODUCTION}

Nitrate leaching from arable land, which causes contamination of groundwater, has become a worldwide environmental concern, and is also considered to be as one of the most important mechanisms of nitrogen losses from soils (Shen et al., 2003, Du et al., 2005 and Zhou et al., 2006). The nitrate losses lead to the low nitrogen use efficiency in different field crops which were grown under diverse environmental conditions (Xing and Zhu, 2000 and Camargo and Alonso, 2006). Most fertilizer nitrogen applied to soils is in the form of ammonium or ammonium producing compounds such as urea, and is usually oxidized rapidly to nitrate by nitrifying microorganisms in soils. Excessive use of readily available conventional chemical fertilizers to agricultural land is the main source of groundwater contamination (Adams et al., 1994, Chang and Entz, 1996 and Fraters et al., 1998). Retardation of the biological oxidation of ammonium can reduce nitrogen losses and decline the groundwater nitrate contamination due to leaching (Amberger, 1989 and Choudhury and Kennedy, 2005). To reduce nitrate leaching from agricultural land, one of the proposals currently being considered for inclusion in regulations is the use of slow-release fertilizers, especially for using the fertilizer added with nitrification inhibitors (NI) (Chen et al., 2003; Morihiro et al., 2003). In temperate soils, ammonium is strongly adsorbed to cation exchange sites, whilst nitrate is highly mobile within the soil. Nitrification inhibitors (NI) are compounds that delay oxidation of the ammonium ion $\left(\mathrm{NH}_{4}^{+}\right)$to nitrate $\left(\mathrm{NO}_{3}{ }^{-}\right)$by suppressing the activity of Nitrosomonas spp. bacteria (Hauck, 1980; Irigoyen et al., 2003). NI can, therefore, theoretically reduce nitrate leaching by retaining nitrogen $(\mathrm{N})$ in a form of low mobility (e.g. $\mathrm{NH}_{4}{ }^{+}-\mathrm{N}$ ) (Shen et al., 2003). On the other hand, NI decrease nitrate concentration in soil, and as a result, they also decrease $\mathrm{N}$ losses through run off (Fettweis et al., 2001) and denitrification (Weiske et al., 2001; Zhu et al., 2003). When the $\mathrm{N}$-use efficiency is improved, and $\mathrm{N}$ doses and the rate of fertilizer applications are decreased, both economic and environmental benefits are achieved. Therefore, nitrification inhibitors have been combined with fertilizers in order to increase fertilizer use efficiency (Walters and Malzer 1990; Boeckx et al. 2005).

The nitrification inhibitor 3, 4-dimethylpyrazole phosphate (DMPP) is highly favourable properties when combined with fertilizers (Zerulla et al. 2001).

\footnotetext{
${ }^{1}$ Water Studies Center, King Faisal University

P.O.Box 420 - Al-Hassa 31982, Saudi Arabia

Email: ahahmed_61@yahoo.com

Received March11, 2009, Accepted March23, 2009
} 
DMPP is effective at low application rates $[0.5-1.5 \mathrm{~kg}$ active component (ac) ha $\left.{ }^{-1}\right]$, has a low solubility in water (i.e. low leaching of DMPP from soil into groundwater), reduces the risk of nitrate leaching and $\mathrm{N}_{2} \mathrm{O}$ losses from soil, does not increase $\mathrm{NH}_{3}{ }^{+}$ volatilization and is not phytotoxic (Zerulla et al. 2001). DMPP is relative immobile in the soil and stays close to where the ammonium is adsorbed, and thus is more effective in inhibiting the nitrification process in soil (Serna et al., 2000, Irigoyen et al., 2003, Roco and Blu, 2006 and Chaves et al., 2006). The objectives of this study are to investigate: 1) Impact of nitrification inhibitor (DMPP) on nitrate leaching in soil. and 2) Increasing the efficiency of nitrogen fertilizer in soil.

\section{MATERIALS AND METHODS}

A laboratory experiment was carried out at Water Studies Center; King Faisal University, Saudi Arabia. Two soils $(0-20 \mathrm{~cm}$ layer) were used in this study. The sandy loam and sandy clay loam soils were collected from two private orchards farms at AL Hassa Oasis in January 2008. The main properties of the experimental soil were done according to the methods outlined in Carter (1993) and the results obtained are shown in Table 1. Each soil sample was air dried, passed through a $2 \mathrm{~mm}$ sieve before packing into PVC columns. Five treatments with three replicates for each were used in this study included; 1) no application of fertilizer (control, designated as C), 2) urea application at a rate of $150 \mathrm{mg} \mathrm{N} /$ column (designated as U), 3) urea application at a rate of $150 \mathrm{mg} \mathrm{N} /$ column added with $1 \%$ of $\operatorname{DMPP}(\mathrm{w} / \mathrm{w})($ designated as U+DMPP), 4) ammonium sulphate application at a rate of $150 \mathrm{mg} \mathrm{N} /$ column (designated as AS) and 5) ammonium sulphate application at a rate of $150 \mathrm{mg} \mathrm{N} /$ column added with $1 \%$ of DMPP(w/w)(designated as AS+DMPP). Fifteen PVC columns for each soil type $(5 \mathrm{~cm}$ inner diameter and $25 \mathrm{~cm}$ height) were vertical located on shelves in the laboratory. The base of each column was covered with two nylon meshes $(<1 \mathrm{~mm})$ with elastic bands to retain the soil. The columns were filled with soil to 1.5 $\mathrm{g} / \mathrm{cm}^{3}$ bulk density. Firstly $300 \mathrm{~g}$ of soil were packed into each column to $10 \mathrm{~cm}$ length, then a $300 \mathrm{~g}$ of soil mixed with $\mathrm{N}$-fertilizers (150 $\mathrm{mg} \mathrm{N} /$ column) were also packed into each column for another $10 \mathrm{~cm}$ length (soil column without $\mathrm{N}$ application were for the control). After that, the top of each column was covered with filter paper to minimize soil disturbance when watering and prevented evaporation. In the first day, distilled water was added into each column to make the soils saturated. In the day 5, $150 \mathrm{ml}$ distilled water was added into each column and leachate was collected in tank. The application of distilled water was repeated at 5,10 , 15, 20, 30, 40 days. Leachate was collected at 5, 10, 15, 20, 30 and 40 days. At completion of the leaching, the nylon meshes were removed, and then soil in each column was pushed out, and was divided into $0-5 \mathrm{~cm}$, 5-10 cm, 10-15 cm and 15-20 cm segments. All soil samples were stored at $4{ }^{\circ} \mathrm{C}$ in fridge until analyzed.

Table 1. Some physical and chemical properties of the soils used in the experiment

\begin{tabular}{|c|c|c|}
\hline Parameters & $\begin{array}{c}\text { Sandy loam } \\
\text { soil }\end{array}$ & $\begin{array}{c}\text { Sandy clay } \\
\text { loam soil }\end{array}$ \\
\hline Sand, \% & 65.7 & 47.4 \\
\hline Silt, \% & 20.2 & 26.3 \\
\hline Clay, \% & 14.1 & 26.3 \\
\hline $\operatorname{ECe}\left(d S ~ m^{-1}\right)$ & 1.54 & 1.85 \\
\hline pH & 7.54 & 7.73 \\
\hline Organic matter, $(\%)$ & 0.63 & 1.12 \\
\hline Available $\mathrm{NO}_{3}-\mathrm{N}\left(\mathrm{mg} \mathrm{kg}^{-1}\right)$ & 12.24 & 27.36 \\
\hline Available $\mathrm{NH}_{4}-\mathrm{N}\left(\mathrm{mg} \mathrm{kg}^{-1}\right)$ & 1.49 & 2.44 \\
\hline Available $\mathbf{P}\left(\mathrm{mg} \mathrm{kg}^{-1}\right)$ & 7.20 & 19.70 \\
\hline Available K (mg kg $\left.{ }^{-1}\right)$ & 74.67 & 124.84 \\
\hline
\end{tabular}

\section{Sample analysis}

Leachate was collected, and its volume and $\mathrm{NH}_{4}{ }^{+}-$ $\mathrm{N}$, and $\mathrm{NO}_{3}{ }^{-}-\mathrm{N}$ concentrations were determined after filtration. The fresh soil samples were extracted by shaking with $2 \mathrm{M} \mathrm{KCl}$ at a soil/solution ratio of 1:5 for $30 \mathrm{~min}$, filtered, and the concentration of $\mathrm{NH}_{4}{ }^{+}-\mathrm{N}$ and $\mathrm{NO}_{3}{ }^{-} \mathrm{N}$ in the filtered extracts was determined by using standard methods (Chapman and Partt 1978, Norman and Stucki, 1981).

The nitrification rate (NR) and inhibition of nitrification (Inhibit.) as \% were calculated according the formula of El-Shazly and Abdel-Nasser (2000) as follows:

$$
\begin{aligned}
& \mathrm{NR}(\%)=\frac{\mathrm{NO}_{3}^{-}-\mathrm{N}}{\left(\mathrm{NO}_{3}^{-}-\mathrm{N}+\mathrm{NH}_{4}^{+}-\mathrm{N}\right)} * 100 \\
& \text { Inhibition of Nitrification }(\%)=\frac{\text { NRof untreated soil }-\mathrm{NR} \text { of treated soil }}{\text { NRof untrated soil }} * 100
\end{aligned}
$$

The ammonium recovery (\%) was calculated as follows (El-Shazly and Abdel-Nasser, 2000):

AmmoniumRecovery $(\%)=\frac{\mathrm{NH}_{4}{ }^{+} \text {in treated soil- } \mathrm{NH}_{4}{ }^{+} \text {in untreated soil }}{\mathrm{NH}_{4}{ }^{+} \text {in untreated soil }} * 100$

All collected data were subjected to statistical analysis of variance according to SAS Software (SAS Institute Inc., 1996).

\section{Effect of DMPP on leaching of $\mathrm{NO}_{3}^{-}-\mathrm{N}$}

The application of urea or ammonium sulphate in the soil increased the amount of $\mathrm{NO}_{3}{ }^{-} \mathrm{N}$ in the leachate compared to those of $\mathrm{C}$ treatment (Fig. 1). Under $\mathrm{C}$ treatments, the highest amount of $\mathrm{NO}_{3}^{-}-\mathrm{N}$ observed in sandy loam soil and sandy clay loam was 1.44 and 2.84 $\mathrm{mg} /$ column, respectively. Under the U or AS treatments, the observed peaks of $\mathrm{NO}_{3}{ }^{-}-\mathrm{N}$ in leachate appeared on day 10 in both soils, with the maximum levels of 5.78 
and $8.02 \mathrm{mg} /$ column in the sandy loam soil treated with $\mathrm{U}$ and AS, respectively. The corresponding values for sandy clay loam soil were 6.66 and $7.22 \mathrm{mg} /$ column for $\mathrm{U}$ and AS treatment, respectively. A slower declining tendency of $\mathrm{NO}_{3}{ }^{-} \mathrm{N}$ in both soils was found from day 10 to day 40, but the amount of $\mathrm{NO}_{3}^{-}-\mathrm{N}$ was still higher than 3.0 and $5.0 \mathrm{mg} /$ column for sandy loam soil treated with $U$ and AS, respectively, and higher than 4.0 and $5.0 \mathrm{mg} /$ column for sandy clay loam soil treated with $\mathrm{U}$ and AS, respectively. Under the DMPP treatment, the amount of $\mathrm{NO}_{3}^{-}-\mathrm{N}$ in the leachate showed a declining tendency within the first 10 or 20 days, e.g. from 3.31 $\mathrm{mg} /$ column on day 5 to $1.76 \mathrm{mg} /$ column on day 20 and from $4.32 \mathrm{mg} /$ column on day 5 to $2.44 \mathrm{mg} /$ column on day 20 in the sandy loam soil treated with U+DMPP and AS+DMPP, respectively. The corresponding values for sandy clay loam soil were from $2.80 \mathrm{mg} /$ column on day 5 to $1.57 \mathrm{mg} /$ column on day 20 and from 3.50 $\mathrm{mg} /$ column on day 5 to $1.93 \mathrm{mg} /$ column on day 20 for
$\mathrm{U}$ and $\mathrm{AS}$ treatment, respectively. Thereafter, the amount of $\mathrm{NO}_{3}^{-}-\mathrm{N}$ were increased slowly over time, and finally reached 3.86 and $5.28 \mathrm{mg} /$ column in the sandy loam soil treated with $\mathrm{U}+$ DMPP and AS+ DMPP, respectively on day 40 and 3.35 and 4.58 $\mathrm{mg} /$ column in the sandy clay loam soil treated with U+DMPP and AS+DMPP, respectively on day 40. It is obvious that the amount of $\mathrm{NO}_{3^{-}}-\mathrm{N}$ under DMPP treatment in both soils were far lower than those under $\mathrm{U}$ and AS treatments consistently because of DMPP addition.

Generally, when DMPP was used, the $\mathrm{NO}_{3}{ }^{-}{ }^{-} \mathrm{N}$ amount in leachate was greatly reduced and decreased the pollution risk to shallow groundwater enormously and the N-use efficiency is improved. Therefore, nitrification inhibitors have been combined with fertilizers in order to increase fertilizer use efficiency (Walters and Malzer 1990; Boeckx et al. 2005).

Sandy loam soil
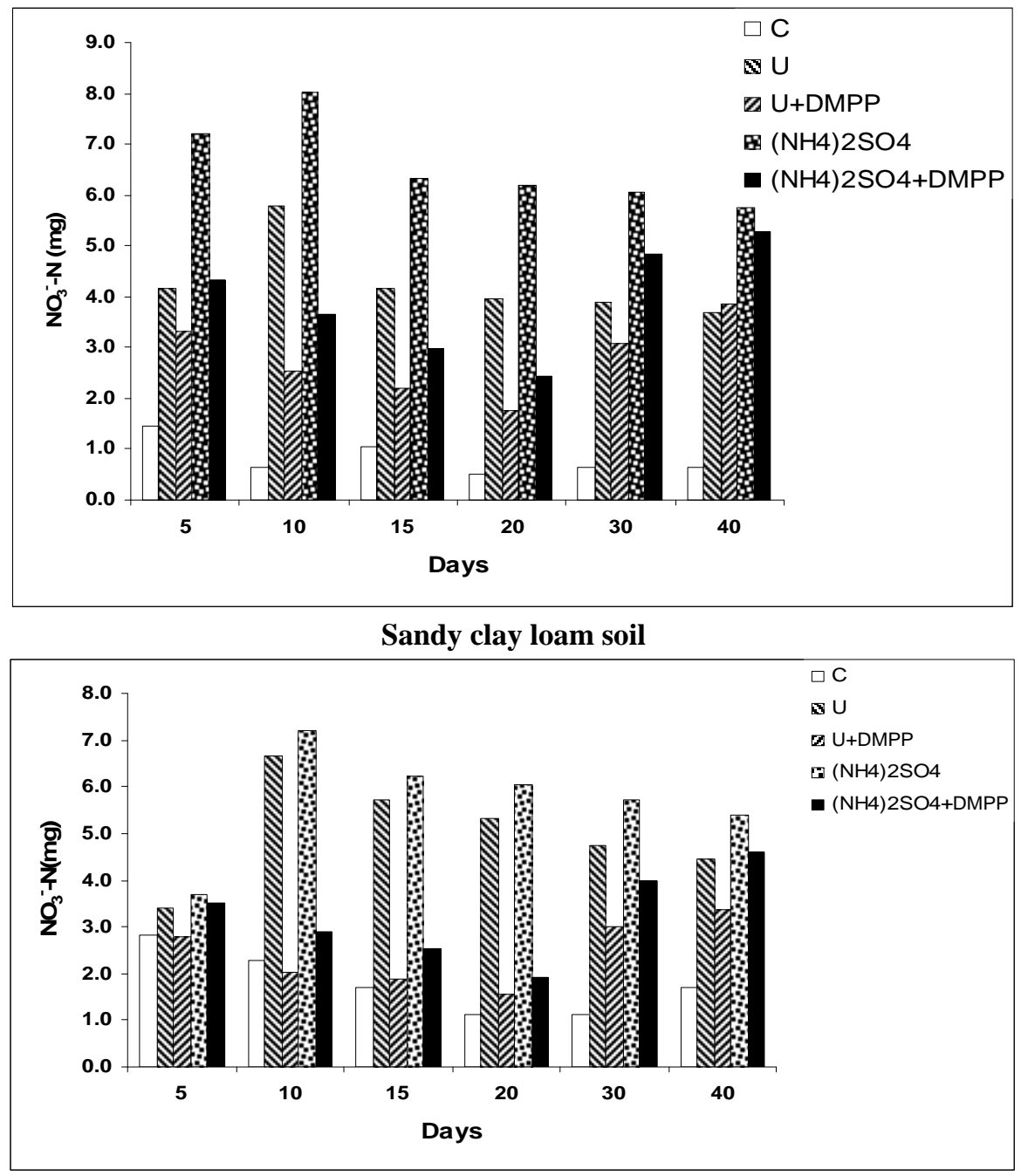

Fig. 1. Change of $\mathrm{NO}_{3}{ }^{-}-\mathrm{N}$ leached from sandy loam and sandy clay loam soils 
The accumulative losses of soil $\mathrm{NO}_{3}{ }^{-}-\mathrm{N}$ in leaching over time are shown in Fig. 2. The accumulative $\mathrm{NO}_{3}^{-}-$ $\mathrm{N}$ loss in the $\mathrm{C}$ treatment was considerably low within the whole period observed, and 4.96 and 10.78 $\mathrm{mg} /$ column of $\mathrm{NO}_{3}{ }^{-} \mathrm{N}$ were lost in columns filled with the sandy loam and sandy clay loam soils within 40 day, respectively. However the accumulative losses of soil $\mathrm{NO}_{3}{ }^{-}-\mathrm{N}$ leaching were increased largely in soil applied with urea or ammonium sulphate, accounting 25.65 and $39.56 \mathrm{mg} /$ column losses in the sandy loam soil treated with $\mathrm{U}$ and AS, respectively at the end of day 40, which were 20.69 and $34.6 \mathrm{mg} /$ column higher than those under the $\mathrm{C}$ treatment. The corresponding values for sandy clay loam soil treated with $\mathrm{U}$ and AS were 30.32 and $34.3 \mathrm{mg} /$ column, respectively at the end of day 40 , which were 19.5 and $23.5 \mathrm{mg} /$ column higher than those under the corresponding $\mathrm{C}$ treatment. However, under the DMPP treatment, the total losses of soil $\mathrm{NO}_{3}{ }^{-}-\mathrm{N}$ via leaching reached 16.76 and 23.50 $\mathrm{mg} /$ column in the sandy loam soil treated with
U+DMPP and AS+DMPP, respectively, which were increased over 11.8 and $18.5 \mathrm{mg} /$ column than the corresponding $\mathrm{C}$ treatment, but were reduced by $34.7 \%$ and $40.6 \%$ of those in the $U$ and AS treatments, respectively. The corresponding values for the total losses of soil $\mathrm{NO}_{3}{ }^{-}-\mathrm{N}$ via leaching from sand clay loam soil treated with U+DMPP and AS+DMPP were 14.65 and $19.41 \mathrm{mg} /$ column, respectively, which were increased over 3.9 and $8.6 \mathrm{mg} /$ column higher than the corresponding $\mathrm{C}$ treatment, but were reduced by $51.7 \%$ and $43.4 \%$ of those in the $\mathrm{U}$ and AS treatments, respectively.

Generally, application of DMPP reduced $\mathrm{N}$ leached in both soils. The loss of $\mathrm{NO}_{3}^{-}-\mathrm{N}$ in the leachate was lower from the soil treated with DMPP than the soil that had received $\mathrm{U}$ or $\mathrm{AS}$ alone during the experimental period. This indicates when DMPP was used, the $\mathrm{NO}_{3}{ }^{-}-$ $\mathrm{N}$ concentrations in leachate was greatly reduced and decreased the pollution risk to shallow groundwater enormously and the $\mathrm{N}$-use efficiency is improved.

Sandy loam soil

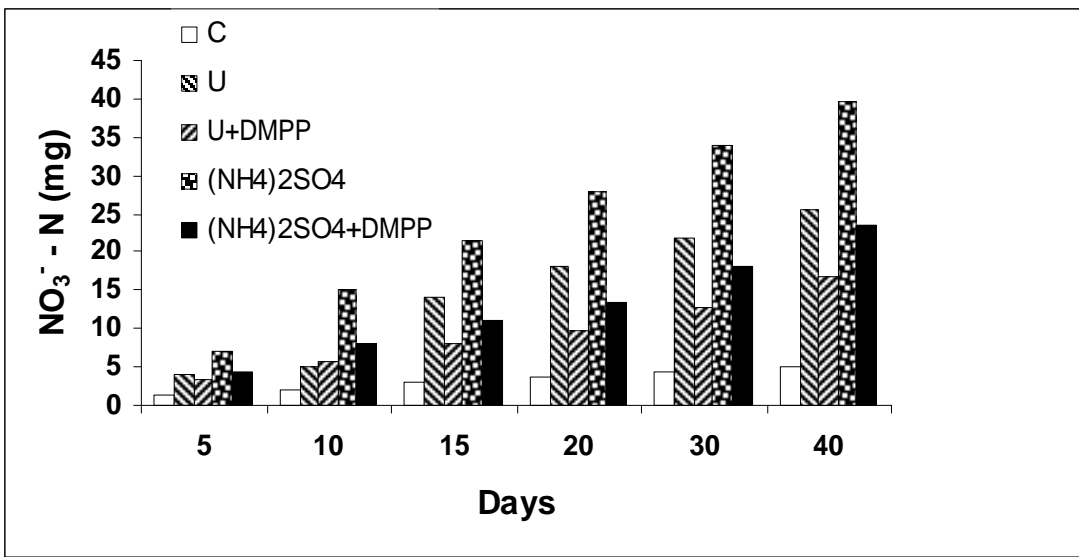

Sandy clay loam soil

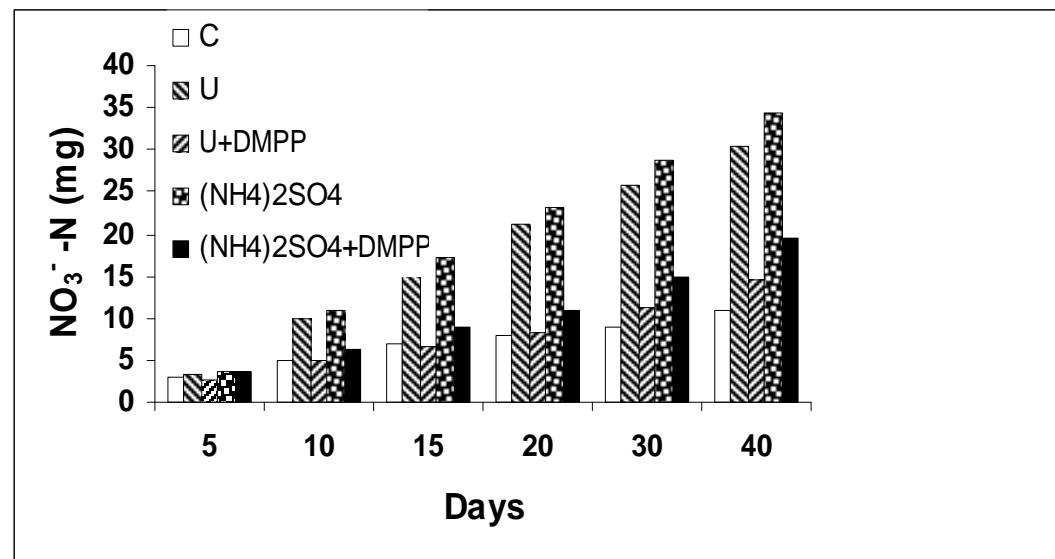

Fig. 2. The cumulative losses of $\mathrm{NO}_{3}{ }^{-} \mathrm{N}$ in the leachate of sandy loam and sandy clay loam soils. 


\section{Effect of DMPP on leaching of $\mathrm{NH}_{4}{ }^{+}-\mathrm{N}$}

The amount of $\mathrm{NH}_{4}{ }^{+}-\mathrm{N}$ in leachate of soil columns were shown in Fig. 3. The amount of $\mathrm{NH}_{4}{ }^{+}-\mathrm{N}$ in leachate in the sandy loam and sandy clay loam soils under $\mathrm{C}$ treatment, tended to vary slightly. Under the $\mathrm{U}$ or AS treatment, the observed peaks of $\mathrm{NH}_{4}{ }^{+}-\mathrm{N}$ in leachate appeared on day 5 in both soils, with the maximum levels of 2.21 and $3.31 \mathrm{mg} /$ column in the sandy loam soil treated with $\mathrm{U}$ and AS, respectively. The corresponding values for sandy clay loam soil treated with $\mathrm{U}$ and $\mathrm{AS}$ were 5.15 and $5.13 \mathrm{mg} /$ column, respectively. A similar trend of $\mathrm{NH}_{4}^{+}-\mathrm{N}$ was found in both soils under the DMPP treatment, with the maximum levels of 6.72 and $8.59 \mathrm{mg} /$ column in the sandy loam soil treated with U+DMPP and AS+DMPP, respectively. The corresponding values for sandy clay loam soil were 9.99 and $12.06 \mathrm{mg} /$ column, respectively. After 15 days, there was no obvious difference of amount of $\mathrm{NH}_{4}{ }^{+}-\mathrm{N}$ among all treatments.
The accumulative losses of soil $\mathrm{NH}_{4}{ }^{+}-\mathrm{N}$ through leaching increased over time (Fig. 4). The accumulative $\mathrm{NH}_{4}{ }^{+}-\mathrm{N}$ loss in the $\mathrm{C}$ treatment was considerably low within the whole period observed, and 0.21 and 0.52 $\mathrm{mg}$ /column of $\mathrm{NH}_{4}^{+}-\mathrm{N}$ were lost in columns filled with the sandy loam and sandy clay loam soils within 40 day, respectively.

However the accumulative losses of soil $\mathrm{NH}_{4}^{+}-\mathrm{N}$ leaching were increased in soil supplied with urea or ammonium sulphate, accounting 5.54 and 7.54 $\mathrm{mg} /$ column losses in the sandy loam soil treated with $\mathrm{U}$ and AS, respectively at the end of day 40, which were 5.33 and $7.33 \mathrm{mg} /$ column higher than those under the $\mathrm{C}$ treatment. The corresponding values for sandy clay loam soil treated with U and AS were $12.86 \mathrm{mg} /$ column and $10.54 \mathrm{mg} /$ column, respectively at the end of day 40 , which were 12.34 and $10.02 \mathrm{mg} /$ column higher than those under the corresponding $\mathrm{C}$ treatment

\section{Sandy loam soil}
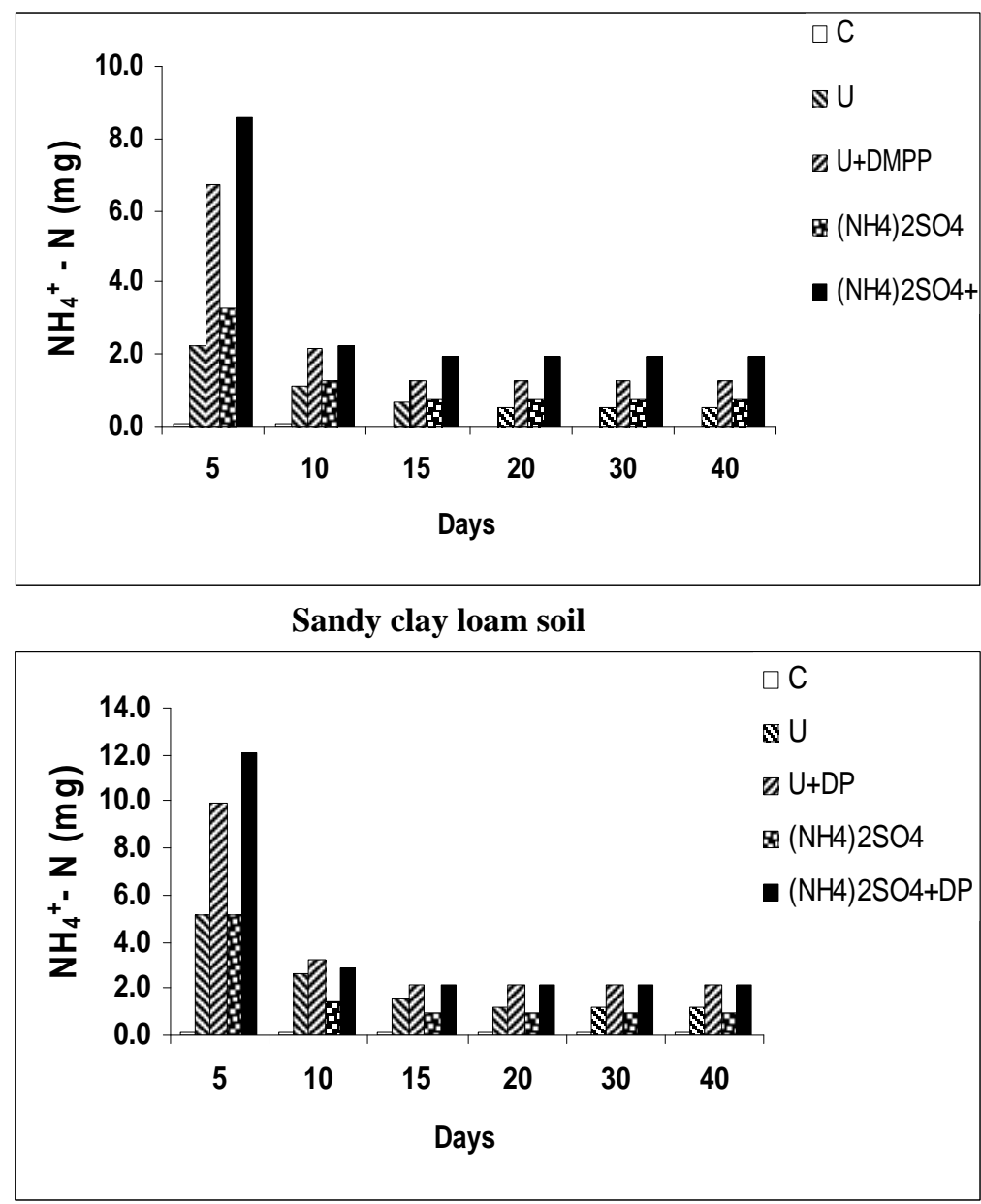

Fig. 3. Change of $\mathrm{NH}_{4}{ }^{+}-\mathrm{N}$ leached from sandy loam and sandy clay loam soils 

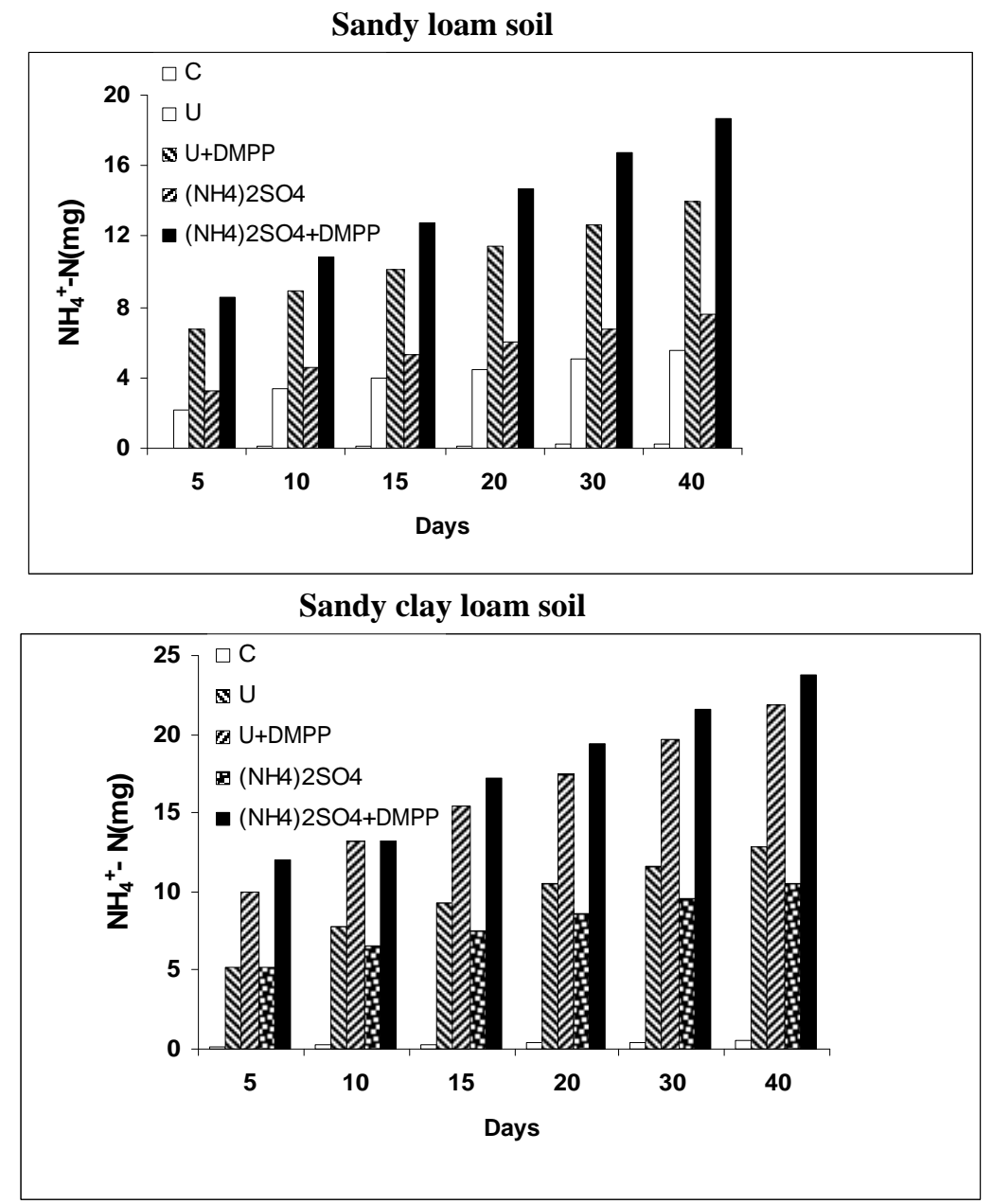

Fig. 4. The cumulative losses of $\mathrm{NH}_{4}{ }^{+}-\mathrm{N}$ in the leachate of sandy loam and sandy clay loam soils

Under the DMPP treatment, the accumulative losses of soil $\mathrm{NH}_{4}{ }^{+}-\mathrm{N}$ from leachate within 40 days were 13.98 and $18.65 \mathrm{mg} /$ column for sandy loam soil treated with $\mathrm{U}$ and AS, respectively; and it was increased over 13.77 and $18.44 \mathrm{mg} /$ column than in respective $\mathrm{C}$ treatment. While, it was over 8.44 $\mathrm{mg} /$ column (152\%) and $11.11 \mathrm{mg} /$ column (147\%) more than under the $\mathrm{U}$ and $\mathrm{AS}$ treatments. Also, the accumulative losses of soil $\mathrm{NH}_{4}^{+}-\mathrm{N}$ from leachate within 40 days for sandy clay loam soil treated with $\mathrm{U}+$ DMPP and AS+ DMPP were 21.87 and 23.76 $\mathrm{mg} /$ column, respectively; and it was increased over 21.35 and $23.24 \mathrm{mg} /$ column than in respective $\mathrm{C}$ treatment, while it was over $9.01 \mathrm{mg} /$ column $(70 \%)$ and $13.22 \mathrm{mg} /$ column $(125 \%)$ more than under the $U$ and AS treatments. The results showed that the losses of $\mathrm{NH}_{4}{ }^{+} \mathrm{N}$ through leaching increased highly with the urea or ammonium sulphate application, but the total losses of $\mathrm{NH}_{4}{ }^{+}-\mathrm{N}$ through leaching was still in a low level; and there was no obvious difference between the $\mathrm{U}$ or
AS treatment and DMPP treatment. The reason might contribute to the strong adsorption character of soil colloid for soil $\mathrm{NH}_{4}{ }^{+}-\mathrm{N}$, so it can't be easily transferred with the movement of water.

\section{Effect of DMPP on inorganic-N losses via leaching}

Total amounts of various $\mathrm{N}$ forms leached from the PVC columns are shown in Table 2. The leachate $\mathrm{NO}_{3}^{-}-$ $\mathrm{N}$ was predominantly and the $\mathrm{NH}_{4}{ }^{+}-\mathrm{N}$ was less. The data showed that the total amounts of inorganic-N $\left(\mathrm{NH}_{4}{ }^{+}-\mathrm{N}\right.$ and $\left.\mathrm{NO}_{3}{ }^{-}-\mathrm{N}\right)$ leaching during 40 days from the soil columns under DMPP treatment were 30.74 and $42.19 \mathrm{mg} /$ column in the sandy loam soil treated with U+DMPP and AS+DMPP, respectively. The corresponding values for the sandy clay loam soil treated with U+DMPP and AS+DMPP were 36.52 and $43.17 \mathrm{mg} /$ column, respectively. Also, Table 2 showed that the total amount of $\left(\mathrm{NH}_{4}{ }^{+}-\mathrm{N}\right.$ and $\left.\mathrm{NO}_{3}{ }^{-}-\mathrm{N}\right)$ leaching during 40 days from the soil columns under $\mathrm{U}$ and AS treatment were 31.19 and $47.08 \mathrm{mg} /$ column in the sandy loam soil treated with $\mathrm{U}$ and AS, respectively. The 
corresponding values for the sandy clay loam soil treated with $\mathrm{U}$ and $\mathrm{AS}$ were 43.18 and 44.84 $\mathrm{mg} /$ column, respectively.

The amount of $\mathrm{NO}_{3}{ }^{-}-\mathrm{N}$ losses was different in the two soils, the fertilizer can be easily leached from sandy loam soil than from sandy clay loam soil, especially the AS and AS+DMPP. However, in both soils, the lowest $\mathrm{NO}_{3}{ }^{-}-\mathrm{N}$ losses were found in the DMPP treatment, and the DMPP can reduce $\mathrm{NO}_{3}^{-}-\mathrm{N}$ significantly from the two soils. Concerning the U or AS application, addition of DMPP with U or AS could effectively reduce 34.7 and $40.5 \%$, respectively, of $\mathrm{NO}_{3}{ }^{-}-\mathrm{N}$ leaching loss from the sandy loam soil. Also, addition of DMPP with $\mathrm{U}$ could effectively reduce $51.7 \%$ of $\mathrm{NO}_{3}{ }^{-}-\mathrm{N}$ leaching loss from the sandy clay loam soil and reduced $43.4 \%$ of $\mathrm{NO}_{3}{ }^{-}-\mathrm{N}$ leaching loss from the sandy clay loam soil when DMPP was applied with AS.

In contrast, the total amount of $\mathrm{NH}_{4}{ }^{+}-\mathrm{N}$ in leachate was higher in the treatment with DMPP. The increases were 152 and $147 \%$ in sandy loam soil treated with U+DMPP and AS+DMPP, respectively. The corresponding values for sandy clay loam soil were 70 and $125 \%$, respectively. The total $\mathrm{N}$ lost was greater in the treatment without DMPP. Also, the results showed that the ratio of $\mathrm{NH}_{4}^{+}-\mathrm{N}$ to $\mathrm{NO}_{3}^{-} \mathrm{N}$ increased with addition of DMPP to U or AS in the two soils used in the present study. For minimizing nitrate leaching and chemical fertilizer cost, regular urea or ammonium sulphate could be applied with 1.0\% DMPP. Therefore, the DMPP is efficient in reducing $\mathrm{N}$ leaching. DMPP added to AS seemed better than added to $\mathrm{U}$.

\section{Soil $N$ content:}

Table (3) clearly indicated that additions of nitrification inhibitors significantly increased soil $\mathrm{NH}_{4}{ }^{+}-\mathrm{N}$ and decreased soil $\mathrm{NO}_{3}{ }^{-}-\mathrm{N}$ in both soils. Such results were attributed to the role of (NI) in inhibiting the biological transformation of soil nitrogen from $\mathrm{NH}_{4}^{+}-\mathrm{N}$ to $\mathrm{NO}_{3}^{-}-\mathrm{N}$ (Mishra et al, 1980 and Chancy and Kamprath, 1982).

In addition, total amounts of inorganic- $\mathrm{N}\left(\mathrm{NH}_{4}{ }^{+}-\mathrm{N}\right.$ and $\left.\mathrm{NO}_{3}{ }^{-} \mathrm{N}\right)$ were found to be markedly decreased as a result of NI additions. The data showed that the total amounts of inorganic-N $\left(\mathrm{NH}_{4}{ }^{+}-\mathrm{N}\right.$ and $\left.\mathrm{NO}_{3}{ }^{-} \mathrm{N}\right)$ in soil for 40 days under DMPP treatment were 72.76 and $72.19 \mathrm{mg} /$ column in the sandy loam soil treated with U+DMPP and AS+DMPP, respectively. The corresponding values for the sandy clay loam soil treated with U+DMPP and AS+DMPP were 94.19 and $92.63 \mathrm{mg} /$ column, respectively. Also, data in Table 3 showed that the total amount of $\left(\mathrm{NH}_{4}{ }^{+}-\mathrm{N}\right.$ and $\left.\mathrm{NO}_{3}{ }^{-} \mathrm{-N}\right)$ in soil for 40 days under $\mathrm{U}$ and $\mathrm{AS}$ treatment were 72.85 and $75.75 \mathrm{mg} /$ column in the sandy loam soil treated with $\mathrm{U}$ and AS, respectively. The corresponding values for the sandy clay loam soil treated with $U$ and AS were $94.85 \mathrm{mg} /$ column and $94.52 \mathrm{mg} /$ column, respectively. Compared to the U or AS application, addition of DMPP with $\mathrm{U}$ or AS could effectively reduce $0.12-4.7 \%$, respectively, of inorganic-N from the sandy loam soil. Also, compared to the U or AS application, addition of DMPP with U or AS could effectively reduce $0.70-2.0 \%$, respectively, of inorganic-N from the sandy clay loam soil.

\section{Nitrification rate $(\%)$ and Inhibition of nitrification (\%):}

Addition of nitrification inhibitors (NI) significantly decreased nitrification rate (NR, \%), Table 3. NR was 36.46 and $27.92 \%$ for sandy loam soil treated with U+DMPP and AS+DMPP, respectively. The corresponding values for the sandy clay loam soil were 43.76 and $36.59 \%$, respectively. Also, the data in Table (3) generally indicated that the inhibition of nitrification process as $\%$ was higher with AS+DMPP than U+DMPP in both soil. The inhibition of nitrification process was $32.43 \%$ and $57.64 \%$ for sandy loam soil treated with U+DMPP and AS+DMPP, respectively. The corresponding values for the sandy clay loam soil were 27.91 and $45.77 \%$, respectively. The ammonium recovery values were 36.99 and $98.20 \%$ for U+DMPP and AS+DMPP, respectively in case of sandy loam soil, while it was 40.90 and $87.74 \%$, respectively in case of sandy clay loam soil. This result indicates that DMPP is more effective with urea than with ammonium sulphate fertilizers. The three mentioned parameters were more indicative for the importance of NI in reducing nitrate losses and increasing the ammonium content in soil, thereby increased the efficient use of $\mathrm{N}$ fertilizers.

\section{Residual $\mathrm{NO}_{3}{ }^{-}-\mathrm{N}$ and $\mathrm{NH}_{4}{ }^{+}-\mathrm{N}$ in the soil}

The results showed that DMPP maintained a higher level of $\mathrm{NH}_{4}{ }^{+}-\mathrm{N}$ and lower level of $\mathrm{NO}_{3}{ }^{-} \mathrm{N}$ in the two soils as compared to $\mathrm{U}$ or AS treatment during the whole periods of experiment (Fig. 5). In the sandy loam soil, $\mathrm{NH}_{4}{ }^{+} \mathrm{N}$ amount was significant greater in the AS+ DMPP than AS alone in every soil depths, also, the sandy loam soil treated with U+DMPP had a higher amount of $\mathrm{NH}_{4}{ }^{+}-\mathrm{N}$ than $\mathrm{U}$ alone in every soil depths. In the sandy clay loam soil $\mathrm{NH}_{4}{ }^{+}-\mathrm{N}$ had the similar trend. In contrast, the amount of $\mathrm{NO}_{3}{ }^{-}-\mathrm{N}$ in two soils treated with DMPP was low as compared with U or AS alone. In the subsoil (15-20 cm layer) of sandy loam soil, the amount of $\mathrm{NO}_{3}^{-}-\mathrm{N}$ was $11.31,7.50,14.70$ and $6.25 \mathrm{mg}$ for U, U+DMPP, AS, AS+DMPP, respectively. In the subsoil ( $15-20 \mathrm{~cm}$ layer) of sandy clay loam soil the amount of $\mathrm{NO}_{3}{ }^{-} \mathrm{N}$ was $16.25,12.15,14.79$ and 8.33 $\mathrm{mg}$ for $\mathrm{U}, \mathrm{U}+\mathrm{DMPP}$, AS, AS+DMPP, respectively. 
Therefore, DMPP could effectively retard the process of $\mathrm{NH}_{4}{ }^{+}-\mathrm{N}$ oxidization to $\mathrm{NO}_{3}^{-}-\mathrm{N}$ within 40 days in the 



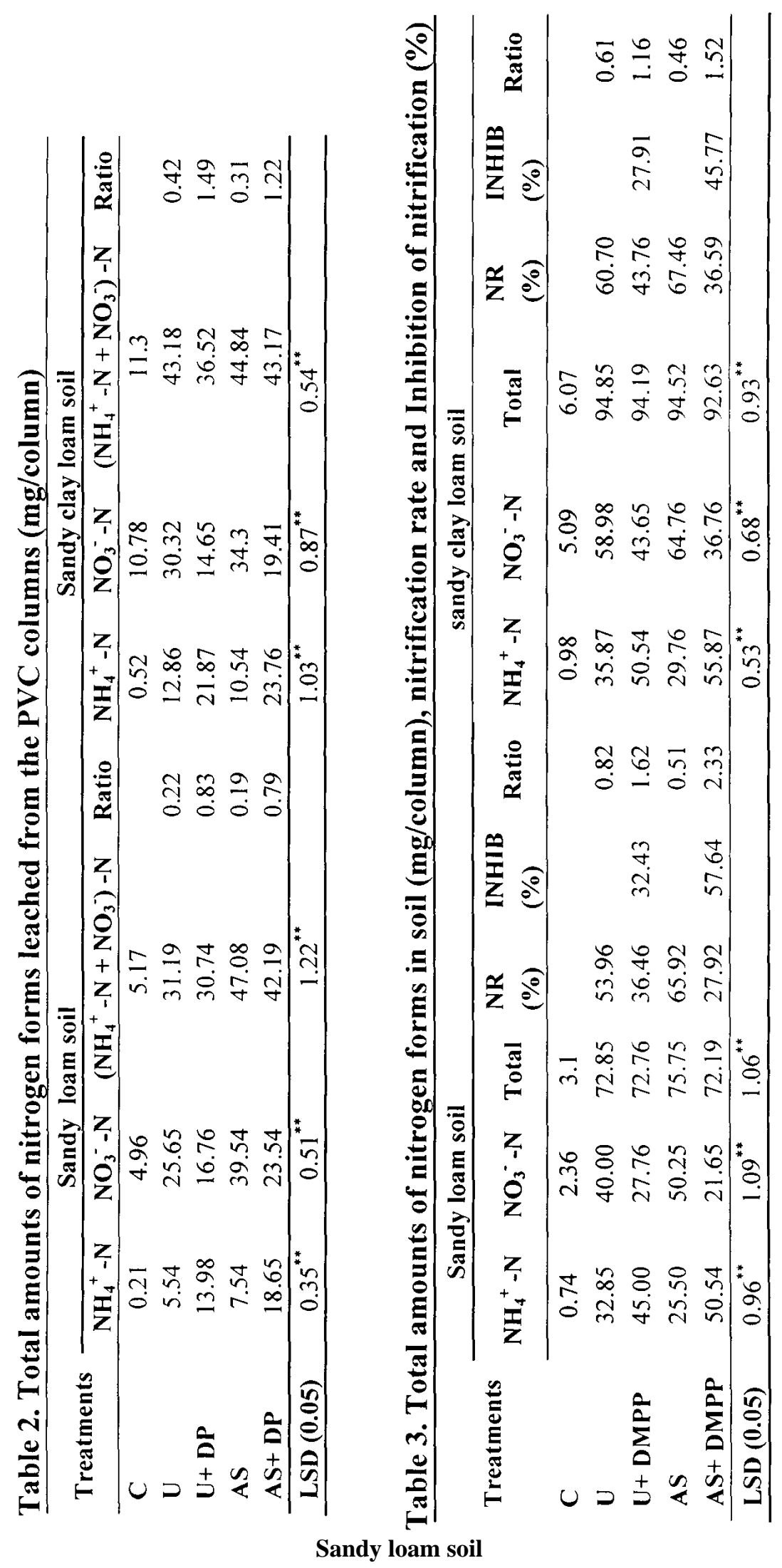




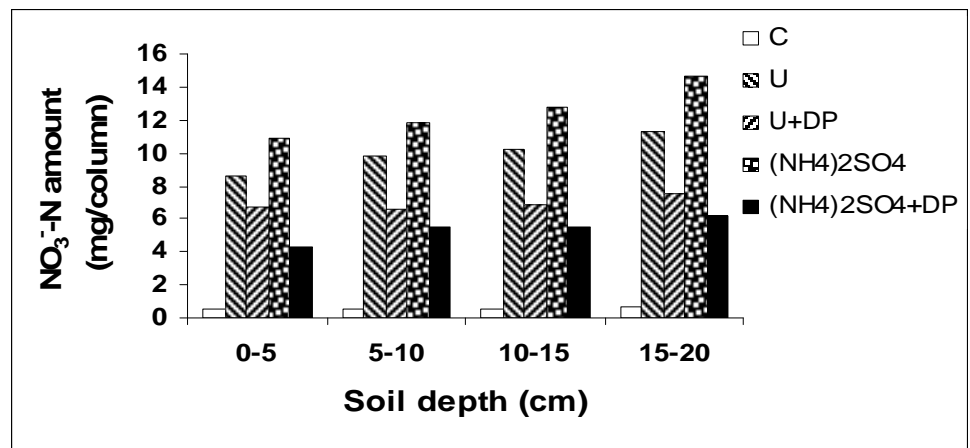

Sandy clay loam soil

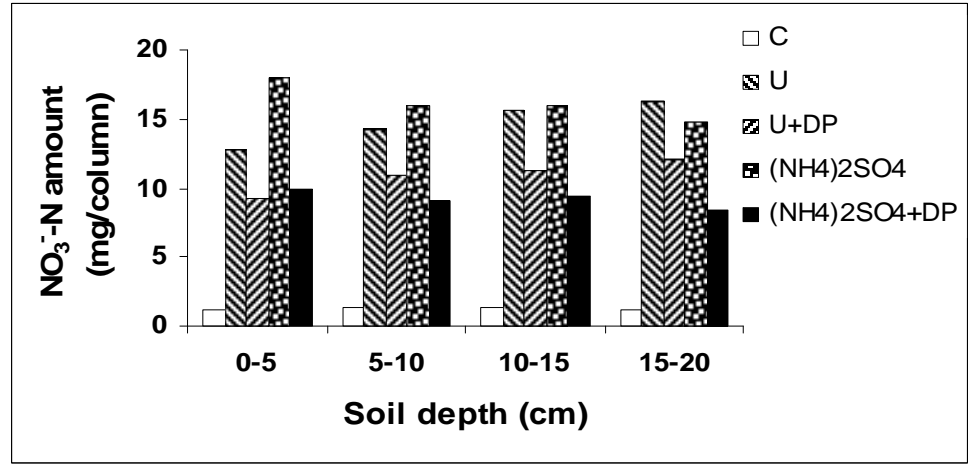

Sandy loam soil

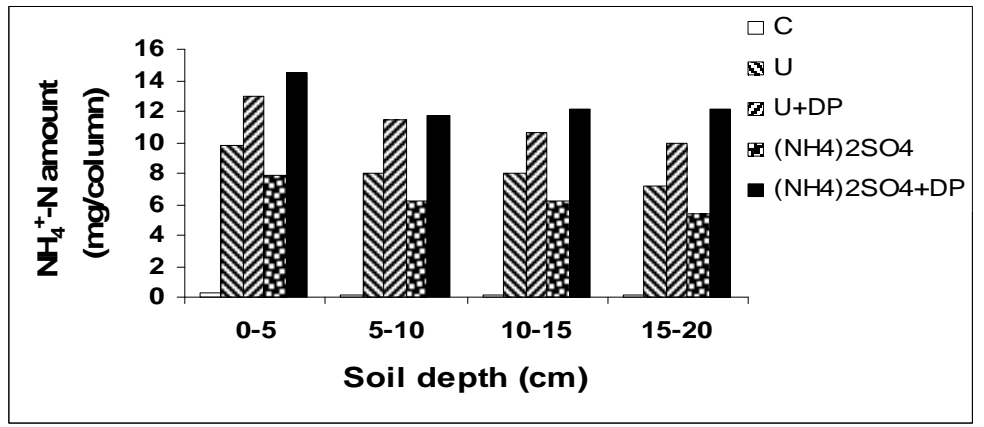

Sandy clay loam soil

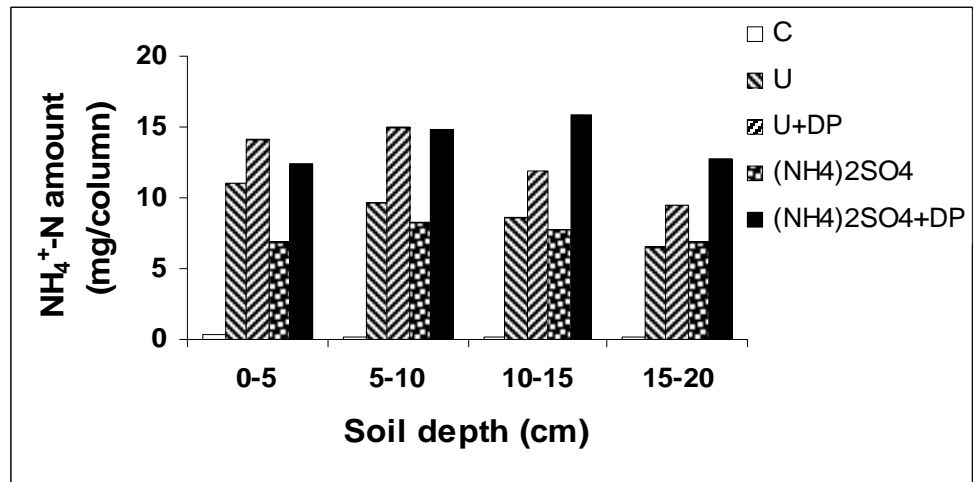

Fig. 5. Amount of $\mathrm{NO}_{3}^{-}-\mathrm{N}$ and $\mathrm{NH}_{4}{ }^{+}-\mathrm{N}$ in different depths of sandy loam and sandy clay loam soils 
sandy loam and sandy clay loam soils, and can reduce nitrate leaching into subsoil layer and U+DMPP was better than AS+DMPP treatments for both soils.

Our results showed that addition of DMPP maintained lower level $\mathrm{NO}_{3}{ }^{-} \mathrm{N}$ and higher level $\mathrm{NH}_{4}{ }^{+}$$\mathrm{N}$ in the leachate (Figs.1 and 3). Although the loss of $\mathrm{NH}_{4}{ }^{+}-\mathrm{N}$ was higher in the treatment with DMPP than without DMPP, which in contrast to $\mathrm{NO}_{3}{ }^{-} \mathrm{N}$, the total $\mathrm{N}$ leached was less in the DMPP treatment. Above results consistent with previous studies (Serna et al., 2000; Xu et al., 2005, Qiaogang et al., 2007 and Shaofu et al., 2007).

The amount of $\mathrm{N}$ lost by leaching was soil-derived $\mathrm{N}$ and fertilizer derived-N. Between soil $\mathrm{N}$ mineralization and immobilization turnover, nitrification inhibitors may cause a priming effect with a subsequent increase in the rate of soil organic matter mineralization and an extra release of soil organic $\mathrm{N}$, so more mineral $\mathrm{N}\left(\mathrm{NO}_{3}{ }^{-}-\mathrm{N}, \mathrm{NH}_{4}{ }^{+}-\mathrm{N}\right)$ will be leached from soil after fertilizer-derived $\mathrm{N}$ was leached almost over (Gioacchini et al., 2002).

The efficiency of nitrification inhibitor depends on soil properties such as temperature, texture, organic matter (Ignacio et al., 2003; Zerulla et al., 2001), this also applies to DMPP. Our results showed that the efficiency of DMPP seems better in the sandy loam soil than sandy clay loam soil. However, only the simultaneous observation of several soil parameters can explain the intensity of inhibition of nitrification by DMPP (Zerulla et al., 2001). Barth et al. (2001) showed with multiple regressions that the sand content, proton concentration as well as microbiological parameters of soil, such as catalase activity, and the potential nitrification capacity, seem to have significant influences on the efficiency of DMPP in soil.

\section{CONCLUSION}

The incorporation of nitrification inhibitor to urea or ammonium sulphate fertilizers can reduce total inorganic- $\mathrm{N}$ losses via leaching. Concerning the nitrification rate (NR), addition of nitrification inhibitors significantly decreased NR in sandy loam and sandy clay loam soils. The ratio of $\mathrm{NH}_{4}{ }^{+}-\mathrm{N}$ to $\mathrm{NO}_{3}{ }^{-}-\mathrm{N}$ increased with addition of DMPP to $\mathrm{U}$ or AS in both soils used in the present study. For minimizing nitrate leaching and chemical fertilizer cost, regular urea or ammonium sulphate could be applied with 1.0\% DMPP.

\section{REFERENCES}

Adams, P.L., T.C. Daniel, D.R. Edwards, D.J. Nichols, D.H. Pote and H.D. Scott. 1994. Poultry litter and manure contributions to nitrate leaching through the vadose zone. Soil Sci. Soc. Am. J., 58:1206-1211.
Amberger, A. 1989. Research on dicyandiamide as a nitrification inhibitor and future outlook. Commun. Soil Sci. Plan., 20:1933-1995.

Barth, G., Tucher, S. and Schinidthalter, U. 2001. Influence of soil parameters on the effect of 3,4-dimethylpyrazole phosphate as a nitrification inhibitor. Boil. Fert. Soils, 34(2): 98-102.

Boeckx, P., Xu, X. and Van Cleemput O. 2005. Mitigation of $\mathrm{N}_{2} \mathrm{O}$ and $\mathrm{CH}_{4}$ emission from rice and wheat cropping systems using dicyandiamide and hydroquinone. Nutrient Cycling in Agroecosystems, 72: 41-49.

Camargo, J.A. and A. Alonso. 2006. Ecological and toxicological effects of inorganic nitrogen pollution in aquatic ecosystems: a global assessment. Environ. Int., 32:831-849.

Carter, M.R. (1993). Soil Sampling and Methods of Analysis. Canadian Society of Soil Science, Lewis Publishers.

Chancy, H. F. and E. K. Kamprath. 1982. Effect of Nitrapyrin on $\mathrm{N}$ response of corn on sandy soils. Agron. J., 74:565569 .

Chang. C. and T. Entz. 1996. Nitrate leaching losses under repeated cattle feedlot manure applications in Southern Alberta. J. Environ. Qual., 25:145-153.

Chapman, H.D. and P.F. Partt. 1978. Methods of analysis for soils, plant and waters. Univ. of California. Div. Agric. Sci., priced Publication 4043.

Chaves, B., A. Opoku, S. De Neve, P. Boeckx, O. Van Cleemput and G. Hofman. 2006. Influence of DCD and DMPP on soil $\mathrm{N}$ dynamics after incorporation of vegetable crop residues. Biol. Fert. Soils, 43:62-68.

Chen, X.M., Shen, Q.R., Pan, G.X., Liu, Z.P. 2003. Characteristics of nitrate horizontal transport in a paddy field of the Tai Lake Region in China. Chemosphere, 50:703-706.

Choudhury, A.T.M.A. and I.R. Kennedy, 2005. Nitrogen fertilizer losses from rice soils and control of environmental pollution problems, Commun. Soil Sci. Plan., 36:1625-1639.

Du, Z.Y., J.M. Zhou, H.Y. Wang, C.W. Du and X.Q. Chen. 2005. Effect of nitrogen fertilizers on movement and transformation of phosphorus in an acid soil. Pedosphere, 15:424-431.

El-Shazly, S. M. and G. Abdel-Nasser. 2000. Influence of some nitrification inhibitors on improving nitrogen fertilizer efficiency and some physiological and biochemical aspects of flame seedless grapevine. Alex. J. Agric. Res., 45(1):249-268.

Fettweis, U., Mittelstaedt, W., Schimansky, C., Fuhr, F., 2001. Lysimeter experiments on the translocation of the carbon-14-labelled nitrification inhibitor 3,4-dimethyl pyrazole phosphate (DMPP) in a gleyic cambisol. Biol. Fert. Soils 34: 126-130.

Fraters, D., J.M. Leo and D. Wim. 1998. Nitrogen monitoring in groundwater in the sandy regions of the Netherlands. Environ. Pollut., 102;479-485. 
Gioacchini, P., Nastri, A. and Marzadori, C. 2002. Influence of urease and nitrification inhibitors on $\mathrm{N}$ losses from soils fertilized with urea. [J]. Biol. Fert. Soils, 36(2): 129-135.

Hauck, R.D. 1980. Mode of action of nitrification inhibitors. In: Meisinger, J.J., Randall, G.W., Vitosh, M.L., Stelly, M., Kroll, D.M., Cousin, M.K. (Eds.), Nitrification Inhibitors Potentials and Limitations. Am. Soc. Agron. Madison, Wisconsin, U.S.A., pp. 19-32.

Ignacio, I., Muro, J. and Azpilikueta, M. 2003. Ammonium oxidation kinetics in the presence of nitrification inhibitor DCD and DMPP at various temperatures. [J]. Aust. J. Soil Res., 41(6): 1177-1183.

Irigoyen, I., J. Muro, M. Azpilikueta, P. Aparicio-Tejo and C. Lamsfus. 2003. Ammonium oxidation kinetics in the presence of nitrification inhibitors DCD and DMPP at various temperatures. Aust. J. Soil Res., 41:1177-1183.

Mishra, M. M. , W. Flaig and H. Soechtig. 1980. The effect of equinoid and phenolic compounds on ureasr and dehydrogenease activity and nitrification in soil. Plant and Soil, 55:25-33.

Morihiro, M., Zhao, B.Z., Ozaki, Y., Tadakatsu, Y. 2003. Nitrate leaching in an Andisol treated with different types of fertilizers. Environ. Pollut., 121:477-487.

Norman, R.J. and J.W. Stucki. 1981. The determination of nitrate and nitrite in soil extracts by ultraviolet spectrophotometry. Soil Sci. Soc. Am. J., 45:347-353.

Qiaogang, Yu., Yingxu Chen, Xuezhu Ye, Qiuling Zhang, Zhijian Zhang and Ping Tian. 2007. Evaluation of nitrification inhibitor 3,4-dimethyl pyrazole phosphate on nitrogen leaching in undisturbed soil columns. Chemosphere, 67: 872-878.

Roco, M.M. and R.O. Blu. 2006. Evaluation of the nitrification inhibitor 3,4-Dimethyl pyrazole phosphate in two Chilean soils, J. Plant Nutr., 29:521-534.

SAS Institute Inc. 1996. The SAS System for Windiows. Release 6.12, SAS Institute Inc., Cary, NC, USA.

Serna, M.D., J. Banuls, A. Quifiones, E. Primo Millo and F. Legaz. 2000. Evaluation of 3, 4-dimethyl pyrazole phosphate as a nitrification inhibitor in a Citrus cultivated soil. Biol. Fert. Soils, 32:41-46.
Shao-fu, W.U., W.U., Liang-huan, SHI Qi-wei, WANG Zhong-qiang, CHEN Xian-you and LI Yong-shan, 2007. Effects of a new nitrification inhibitor 3,4dimethylpyrazole phosphate (DMPP) on nitrate and potassium leaching in two soils. J. Environ. Sci., 19: 841-847.

Shen, Q.R., W. Ran and Z.H. Cao. 2003. Mechanisms of nitrite accumulation occurring in soil nitrification. Chemosphere, 50:747-753.

Walters, D.T. and Malzer, G.L. 1990. Nitrogen management and nitrification inhibitor effects on nitrogen-15 urea: II. Nitrogen leaching and balance. Soil Sci, Soc, Am. J., 54:122-130

Weiske, A., Benckiser, G., Herbert, T. and Ottow, J., 2001. Influence of the 3,4-dimethyl pyrazole phosphate (DMPP) in comparison to dicyandiamide (DCD) on nitrous oxide emission, carbon dioxide fluxes and methane oxidation during 3 years of repeated application in field experiments. Biol. Fert. Soils. 34, 109-117.

Xing, G.X. and Z.L. Zhu. 2000. An assessment of N loss from agricultural fields to the environment in China. Nutr. Cycl. Agroecosys, 57:67-73.

$\mathrm{Xu}, \mathrm{C} . \mathrm{Wu}, \mathrm{L} . \mathrm{H}$. and Ju, X. T. 2005. Role of nitrification inhibitor DMPP (3,4-dimethylpyrazole phosphate) in NO3--N accumulation in greengrocery (Brsssica campestris L. ssp. chinensis) and vegetable soil. J. Environ. Sci., 17(1): 81- 83.

Zerulla, W.T. Barth, J. Dressel, K. Erhardt, K.H. Von Locquenghien, G. Pasda, M. R?dle and A.H. Wissemeier. 2001. 3,4-Dimethyl pyrazole phosphate: a new nitrification inhibitor for agriculture and horticulture. Biol. Fert. Soils, 34:79-84.

Zhou, J.B. J.G. Xi, Z.J. Chen and S.X. Li. 2006. Leaching and transformation of nitrogen fertilizers in soil after application of $\mathrm{N}$ with irrigation: a soil column method. Pedosphere, 16;245-252.

Zhu, J.G., Zhu, G. Liu, Y. Han, Y.L. Zhang and G.X. Xing. 2003. Nitrate distribution and denitrification in the saturated zone of paddy field under rice/wheat rotation. Chemosphere, 50:725-732. 


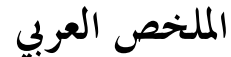

\section{تحسين كفاءة السماد النيتروجيني في التربة بأستخدام مثبط النترتة (DMPP)}

\author{
عادل حسين أحمد حسين

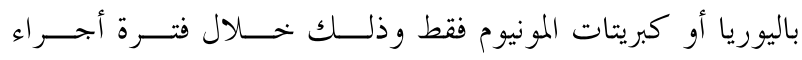 \\ في هذة الدراســة تم اسـتخدام DMPP (3,4-dimethyl

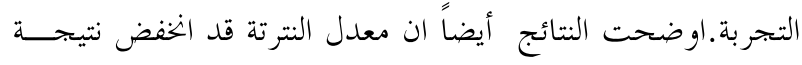 \\ كمادة مثبطة للنتر تــة وذلــك لتثبـيط pyrazole phosphate)

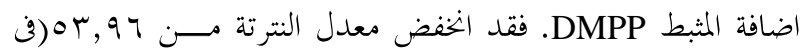 \\ التحولات النيتروجينية في التربة وكذلك خفض غسيل النتـرات في

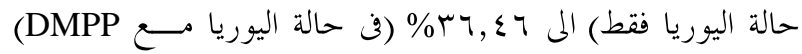 \\ نوعين من التربة هما رملية لومية ورملية طينية لومية. تم تعبئة أعمدة

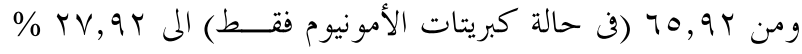

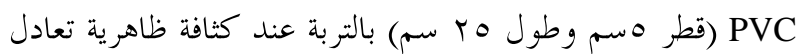

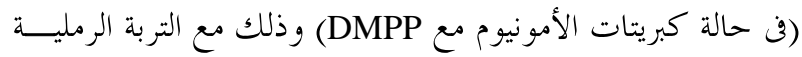

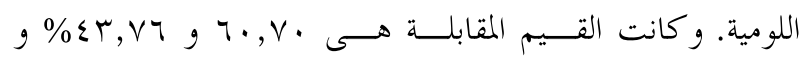

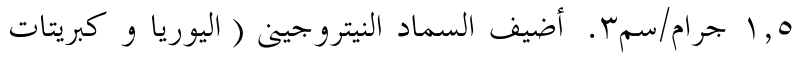

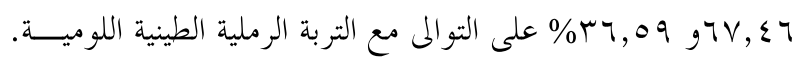

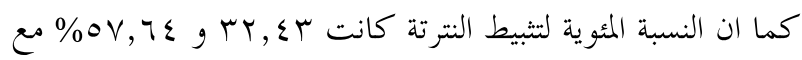

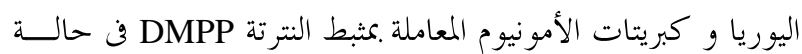

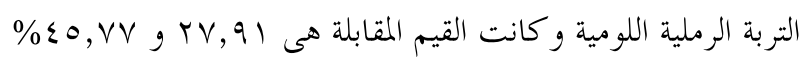

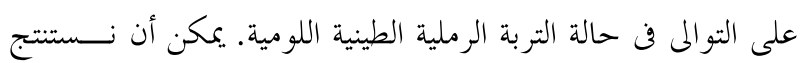

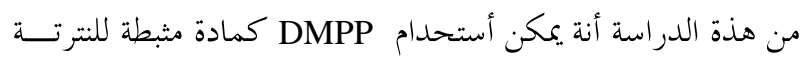

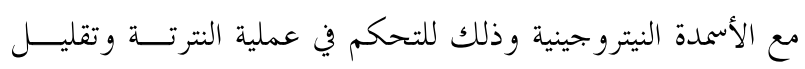

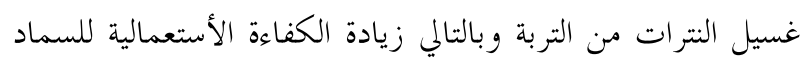

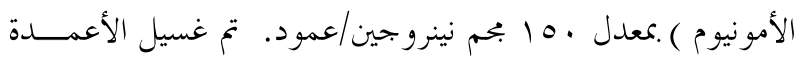

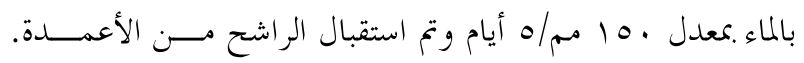

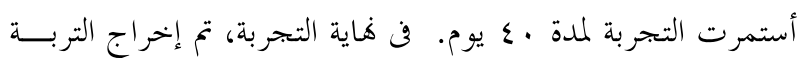

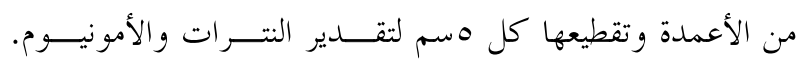

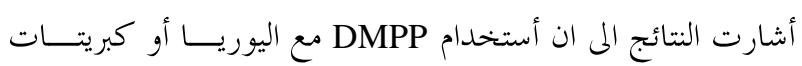

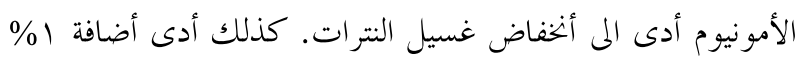

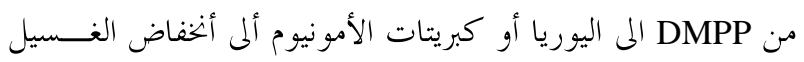

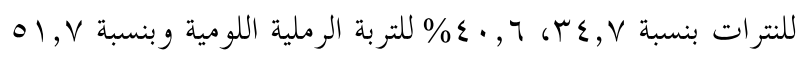

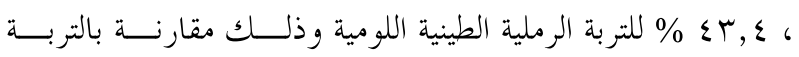

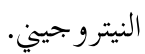

